\title{
Potential exposure to diclofenac in Spain of European vultures
}

\author{
Alvaro Camiña ${ }^{1 *}$, Jose Aguilera ${ }^{2}$, François Sarrazin $^{3}$ and Olivier Duriez ${ }^{4}$ \\ ${ }^{1}$ ACRENASL Environmental Consultants, Apartado de Correos 339, 28220 Majadahonda, Spain. \\ ${ }^{2}$ Colectivo Azálvaro, Calle Real 36 3-B, 40400 El Espinar, Spain. \\ ${ }^{3}$ UPMC Sorbonne Université, CESCO UMR 7204 MNHN-CNRS-UPMC, 61 rue Buffon, 75005 Paris, France. \\ ${ }^{4}$ Université de Montpellier 2, CEFE - UMR 5175, Campus du CNRS, 1919 Route de Mende, F-34293 Montpellier, France \\ * Corresponding author: acamia@acrenasl.eu
}

http://dx.doi.org/10.4314/vulnew.v75i1.1

\begin{abstract}
Diclofenac (NSAID) for veterinary use, the same that previously reduced south Asian Gyps vulture populations by nearly 99\% in the late 1990s, was approved in Spain in 2013 for cattle, swine and horses. We assessed its availability and the potential exposure to European Griffon Gyps fulvus, Cinereous Aegypius monachus, Egyptian Neophron percnopterus and Bearded vultures Gypaetus barbatus in Spain. In 2014, a telephone questionnaire to 1073 official pharmaceutical distributers (POS) found 230 responses and 82 were currently selling diclofenac. The preliminary assessment for Spain showed a widespread exposure to diclofenac that extends across $275,391 \mathrm{~km}^{2}$, i.e. $54 \%$ of the territory. Diclofenac availability is related to livestock densities and certain rearing practices, especially cattle and extensive swine farming, but not with horse farms. Livestock farming carcass disposal practices and subsequent carcass availability to vultures are of concern when controlling for diclofenac potential use and residues in corpses. Overlap of diclofenac exposure with vulture distribution ranges and population sizes per region were highest for Cinereous Vulture (88\% and $73 \%$ overlap with range and population size respectively), 62/56\% for the Egyptian Vulture, 58/57\% for the Griffon and $42 / 36 \%$ for the Bearded Vultures. Ensuring the safety of carcasses consumed by vultures with specific tests for NSAIDs and their use in farming practices is required.
\end{abstract}

\section{Introduction}

The veterinary use of diclofenac, a non-steroidal anti-inflammatory drug (NSAID), was responsible for a $99 \%$ decline of three Gyps vulture species in south Asia (Prakash et al. 2003, Cuthbert et al. 2006). Vultures died as early as 36 hours after feeding on carcasses recently treated with diclofenac, which caused renal failure and visceral gout in the birds (Oaks et al. 2004). Predictive models showed that only
$0.1-0.8 \%$ of available carcasses containing lethal levels of diclofenac were needed to cause the observed population declines of vultures in India (Green et al. 2004). Further studies demonstrated that other vulture species were also susceptible and at risk from NSAIDs (Cuthbert et al. 2006; Swan et al. 2006a). These keystone species and exclusive scavengers provide a critical ecosystem service, sanitizing the environment through the recycling and removal of carcasses. The loss of these species 
directly threatens ecosystem function (Şekercioğlu et al. 2004). Conservation efforts in Asia focused on banning both the import, manufacture and use of veterinary diclofenac, and had success in 2006 in India, Nepal and Pakistan, followed in 2010 in Bangladesh (Cuthbert et al. 2011). It was only after the ban of veterinary diclofenac that the precipitous declines in the vulture populations began to slow. The estimated societal cost associated with the vulture population crash between 1998 and 2008 was estimated annually to be 34 billion USD (Markandya et al. 2008) and, though declines of the vulture populations have slowed with some potential reversal, they are still very far from recovery.

Nevertheless, in 2013 the Spanish Government approved the use of both Dolofenac and Diclovet, two veterinary drugs containing diclofenac sodium for swine, cattle and horses, and similar authorizations occurred in Italy and Slovenia (Camiña et al. 2014, Margalida et al. 2014). Nearly $98 \%$ of Europe's four vulture species occur in Spain, but also in Portugal and France (De la Puente et al. 2007, Del Moral 2009, Del Moral \& Martí 2002). If misuse of veterinary diclofenac as occurred in south Asia is repeated, conservation of European vultures could be compromised. Shortly after the approval of diclofenac in Spain, some opinions suggested a lower risk to European vultures because farmers in Europe were assumed to employ better husbandry practices and food management provision for vultures, compared to Asia. This was the conclusion of a report by three Ministries of the National Spanish Government (AEMPS \& MAGRAMA 2014). However, the real effect of diclofenac and other NSAIDs on scavenging birds in Europe could be overlooked (Zorrilla et al. 2014). It is therefore important to collect data on the potential exposure of vultures to diclofenac, through reliable surveillance of carcasses and specific analyses for NSAIDS, none of which is routinely performed when determining cause of death (Richards et al. 2014). A paper by Green et al. (2016) modelled the potential effect of veterinary diclofenac on the Griffon Vulture Gyps fulvus in Spain, highlighting that the previous calculations by AEMPS \& MAGRAMA (2014) would have been underestimates. The potential effect of the drug would depend not only on vulture population parameters but also on livestock rearing practices, because it is the time elapsed between diclofenac administration and the death of the treated ungulate that affects toxicity to feeding vultures. For this purpose, Green et al. (2016) suggest that the only way to estimate risk is to measure diclofenac residues in tissues from carcasses at feeding stations.

In Spain, there are two livestock farming practices: "extensive" where livestock graze freely in open pastures, usually year-round, or depending on climate conditions; and "intensive" where animals are confined indoors at varying densities. Vultures can feed either on carcasses coming from "extensive" or "intensive" livestock rearing systems, with the difference being based on how carcasses are managed and disposed of after death. In extensive areas cattle, sheep, goats, swine or horses are not permanently under surveillance by shepherds, which increases the opportunity for vultures to locate and feed on carcasses before they are removed (Supplementary Material Figure S8). Remarkable in Spain is the savannah-like landscape named "dehesa" (Donázar et al. 1997) that is dominated by evergreen Holm Quercus ilex and Cork $Q$. suber oaks, and extends through south-western, central and southern Spain (mainly Andalusia and Extremadura). Because these pastures are at lower altitudes and the climate is milder, they 
are available for grazing most of the year. At higher elevations like mountain ranges, livestock normally remain on pasture from May to October, being in confinement during late autumn and winter. Vultures forage for carcasses over these large geographic areas. By contrast, when feeding at feeding stations, vultures access carcasses that come from intensive farming (Camiña \& Montelío 2006, Supplementary Material Figures S9-S10). Swine carcasses predominate at feeding stations, following the restriction of cattle carcasses after the Bovine Spongiform Encephalopathy-BSE crisis. For decades, swine carcass disposal at vulture restaurants has been one of the reasons for the increase in Griffon vulture populations in northern Spain (Camiña 2004). These carcasses are constantly under shepherd control from the time of death until they are dropped off at the feeding station.

In this study, we modelled the potential exposure of vultures to veterinary diclofenac in Spain using a method different to Green et al. (2016) and also by considering four species of vultures. We estimate: 1) the current geographic selling distribution and points of sale (POS) for diclofenac and 2) how these POS are spread in relation to livestock rearing practices, vulture species distribution and population sizes. We then discuss diclofenac exposure according to carcass disposal procedures and potential availability to vultures.

\section{Material and methods}

We completed a phone questionnaire among the seventeen administrative regions of Spain during April-May 2014. We used the list of Official POS of Agrochemicals and Veterinary Drugs available either from the National (www.magrama.gob.es) or Local Governments. POS were sorted by addresses and phone numbers, and this list was reduced further because many POS had ceased activity by the time of the questionnaire. POS selling only agrochemicals but not veterinary drugs were also removed from the list leaving a potential sample size of 1073 POS (Table 1). One of us (JA) is from Colectivo Azálvaro, an approved and registered establishment by the Spanish authorities that handles animal by-products and derived products for feeding necrophagous birds (register available at: http://sandach.marm.es/Publico/Estab.aspx). The Colectivo Azálvaro has associated farmers authorised to provide carcasses to feeding stations managed by the Colectivo, and these farmers were in charge of making the survey calls. All surveys were carried out with the agreement of the respondents, and the survey had ethical clearance that complied with the ethical standards of the Helsinki Declaration of 1975, as revised in 2008. Diclofenac use requires a veterinary prescription so farmers called POS and asked about diclofenac availability; if diclofenac was not currently sold, we requested the time required for having the drug available for sale and its price. Survey respondents were defined as commercial sellers of veterinary drugs for livestock treatment, and a positive answer was one that confirmed the sale of diclofenac or its availability in less than a week.

We calculated the estimated number of POS per region where diclofenac could be available as $=$ (number of positive calls to diclofenac availability X number of POS registered) / number of POS called. We also estimated the level of potential exposure to diclofenac (POS selling the drug per unit area) by obtaining an abundance index or area of exposure, calculated as: (number of POS selling drug in the region $\mathrm{X}$ number of POS listed) / (number of POS 
surveyed $X$ area). In this case, the number of POS called is the number of total calls.

Diclofenac is licensed in Spain for use in cattle, swine and horses. We used the 2009 census of these species from the National Institute of Statistics (INE 2014) to determine the animal farming system (extensive versus intensive) and the open pasture surface area where livestock graze in each administrative region (Table 2). We calculated the livestock density as the number individuals of each livestock type per square kilometre and then compared the POS abundance index with the livestock rearing densities using Spearman rank correlations. We tried to find if the diclofenac POS abundance index was related with certain animal husbandry practices.

The potential distribution of the POS of diclofenac does not reflect the exact location of the farmers using it. Although farmers can purchase veterinary drugs anywhere, they usually buy them at veterinary pharmacies that are near the veterinarians that care for their animals within their respective political regions (Colectivo Azálvaro pers. comm.).

When considering the foraging range of vultures (which differs with age, breeding status, and season), we selected a conservative average of $50 \mathrm{~km}$ foraging radius from breeding sites as appropriate for nesting pairs (Costillo et al. 2007 and references therein, Monsarrat et al. 2013, Lopez-Lopez et al. 2014, authors' unpub. data). Migratory species (like the Egyptian Vulture) or immature birds are known to exceed such distances and even regional boundaries when feeding on carcasses, but were not taken into account for the analysis. We used each POS as though it were a site where an animal was treated with diclofenac, georeferenced each POS location in the Iberian Peninsula, and calculated a buffer area of $50 \mathrm{~km}$ around them using Arc GIS 10.2. ESRI Inc, www.esri.com. Using the average foraging radius of vultures noted above, we assumed the populations of all species included within the buffer area to be the most exposed to diclofenac.

Distribution ranges of the Griffon, Cinereous (Aegypius monachus), Egyptian (Neophron percnopterus) and Bearded (Gypaetus barbatus) vultures were taken from presence/absence data provided on a $10 \times 10 \mathrm{~km}$ UTM grid available in shape format at www.magrama.gob whilst the population numbers were taken from the latest breeding censuses available (De la Puente et al. 2007, Del Moral \& Martí 2002, Del Moral 2009 and Razin 2014). For the potential exposure we then calculated both the overlap of the buffers around the POS and the $10 \times 10$ squares occupied per vulture species distribution range and population sizes.

\section{Results}

Out of 230 respondents, 82 (36\%) POS were selling a diclofenac-based veterinary drug with a total estimate of 238 for the whole country (Table 1). The distribution of diclofenac POS was widespread all over Spain. The abundance index showed the highest values > 1 (1 POS $1000 \mathrm{~km}^{-2}$ ) at four, and quite separate, areas in northern (GA, CAN), western (EX) and southeastern (MU) Spain (Figure 1). A second group, with values $>0.5$, includes the south (AN), north (AS) and the Balearic Islands. For three regions (BC, CI and VAL) no POS were found. 


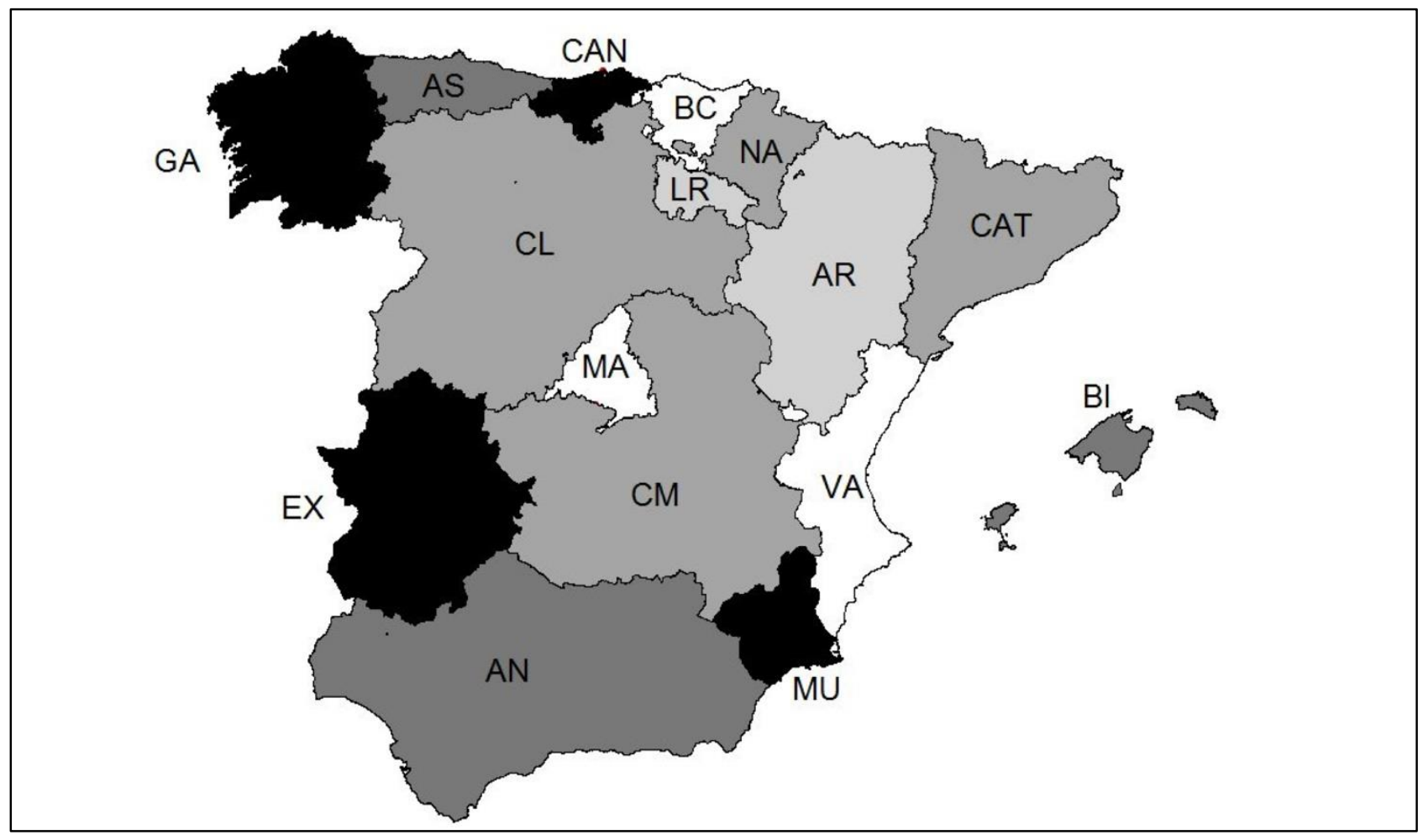

Figure 1: Map of Spain showing the points of sale (POS) abundance index per region (Estimated selling points $1000 \mathrm{~km}^{-2}$ ): Black (> 1), Dark Grey (0.5-1), Medium Grey (0.25-0.49), Light Grey $(>0-0.24)$ and White (0.00). See Table 1 for codes of regions. Map for the Canary Islands omitted because no POS have been registered there. 
Table 1: Spanish administrative regions and their areas, number of registered and called points of sale (POS) and those that resulted in effective calls and positives to diclofenac. For the estimated POS per region and POS abundance index see methods.

\begin{tabular}{|c|c|c|c|c|c|c|c|}
\hline Region (code) & $\begin{array}{r}\text { Area } \\
(\mathrm{sq} . \mathrm{km})\end{array}$ & $\begin{array}{c}\text { Registered } \\
\text { (a) }\end{array}$ & $\begin{array}{c}\text { Called } \\
\text { (b) }\end{array}$ & $\begin{array}{c}\text { Effective calls } \\
\text { (c) }\end{array}$ & $\begin{array}{c}\text { Positives } \\
\text { DICL } \\
\text { (d) }\end{array}$ & $\begin{array}{c}\text { Estimated } \\
\text { POS/region } \\
{[(\mathrm{d}) \times(\mathrm{a})] /(\mathrm{b})}\end{array}$ & $\begin{array}{l}\text { Abundance index POS } \\
{\left[((\mathrm{d}) \times(\mathrm{a})) /(\mathrm{b})^{*}(\mathrm{sq} \cdot \mathrm{km})\right] \times 10^{3}}\end{array}$ \\
\hline Andalusia (AN) & 87599 & 212 & 79 & 40 & 17 & 46 & 0.52 \\
\hline Asturias (AS) & 10604 & 44 & 6 & 2 & 1 & 7 & 0.69 \\
\hline Basque Country (BC) & 7234 & 2 & 2 & 0 & - & - & - \\
\hline Canary islands $(\mathrm{CI})$ & 7447 & 22 & 5 & 1 & 0 & 0 & 0.00 \\
\hline Castilla Leon (CL) & 94224 & 221 & 105 & 56 & 13 & 27 & 0.29 \\
\hline Catalonia (CAT) & 32113 & 67 & 19 & 10 & 4 & 14 & 0.43 \\
\hline Extremadura (EX) & 41634 & 127 & 40 & 29 & 17 & 54 & 1.29 \\
\hline Galicia (GA) & 29575 & 46 & 6 & 6 & 4 & 31 & 1.03 \\
\hline Balearic Islands (BI) & 4992 & 16 & 16 & 16 & 3 & 3 & 0.60 \\
\hline La Rioja (LR) & 5045 & 6 & 6 & 4 & 1 & 1 & 0.19 \\
\hline Madrid (MA) & 8028 & 17 & 1 & 1 & 0 & 0 & 0.00 \\
\hline
\end{tabular}


Table 2: Livestock censuses (individuals $\mathrm{km}^{-1}$ ) of swine, horses and cattle in Spain after INE (2014). It also shows the percentage of open pastures per region according to their territories and percentage of dehesa these pastures comprise.

\begin{tabular}{|c|c|c|c|c|c|c|c|c|}
\hline \multirow{2}{*}{ Region } & \multicolumn{2}{|c|}{ Swine } & \multirow{2}{*}{$\begin{array}{c}\text { Carcass } \\
\text { Swine disposal }\end{array}$} & \multirow{2}{*}{ Horses } & \multicolumn{2}{|c|}{ Cattle } & \multirow{2}{*}{$\begin{array}{c}\begin{array}{c}\text { Total Pastures } \\
\left(\mathrm{km}^{2}\right)\end{array} \\
\text { Include } \\
\text { dehesa }\end{array}$} & \multirow{2}{*}{$\begin{array}{c}\text { Pastures only dehesc } \\
\left(\mathrm{km}^{2}\right)\end{array}$} \\
\hline & Intensive & Extensive & & & $\begin{array}{r}\text { Intensive } \\
\text { (dairy) }\end{array}$ & $\begin{array}{r}\text { Extensive } \\
\left(\text { meat }^{4}\right)\end{array}$ & & \\
\hline Aragon (AR) & 114.17 & - & F. Site & 0.09 & 0.26 & 0.44 & $15.18 \%$ & - \\
\hline Asturias (AS) & 1.79 & - & - & 1.80 & 8.45 & 28.27 & $21.19 \%$ & - \\
\hline Basque Country (BC) & 4.30 & - & F. Site & 1.05 & 3.56 & 1.58 & $13.88 \%$ & - \\
\hline Canary Isl. (CI) & 14.23 & - & - & 0.24 & 2.62 & 3.97 & $15.70 \%$ & - \\
\hline Castilla Leon (CL) & 36.23 & 0.17 & F.site/Extensive & 0.14 & 0.12 & 12.84 & $26.02 \%$ & $16.19 \%$ \\
\hline Catalonia (CAT) & 20.16 & - & F. Site & 0.60 & 0.32 & 4.15 & $10.62 \%$ & - \\
\hline Extremadura (EX) & 202.60 & 23.80 & F.site/Extensive & 0.29 & 2.45 & 14.50 & $48.45 \%$ & $54.38 \%$ \\
\hline Galicia (GA) & 49.57 & - & - & 0.48 & 0.26 & 1.93 & $0.62 \%$ & - \\
\hline Illes Balears (IB) & 4.69 & - & No disposal & 0.68 & 0.23 & 16.00 & $71.14 \%$ & - \\
\hline La Rioja (LR) & 39.71 & - & F. Site & 0.64 & 12.20 & 20.65 & $45.18 \%$ & - \\
\hline
\end{tabular}

Notes: Carcasses of dead animals from intensive and extensive farming systems may be moved to a vulture feeding site. Carcasses from extensive farming may also be fed upon by vultures in the place where they die, before the carcass can be removed by the farmer. No carcasses from either meat or dairy cattle are dropped off at vulture restaurants after the BSE crisis from 2000 afterwards. 
Overall, only one of the respondents in Navarre had already sold the drug and only eight (10\%) clearly requested a prescription written by a veterinarian after farmers expressed the intention to buy. All the remaining POS just accepted our willingness to buy, stating its availability within the next $24-48$ hours. In terms of area of influence based on buffers around POS, the potential exposure area extends over 275,391 sq. $\mathrm{km}$, which represents $54 \%$ of the Spanish territory including both archipelagos (Figure 2).

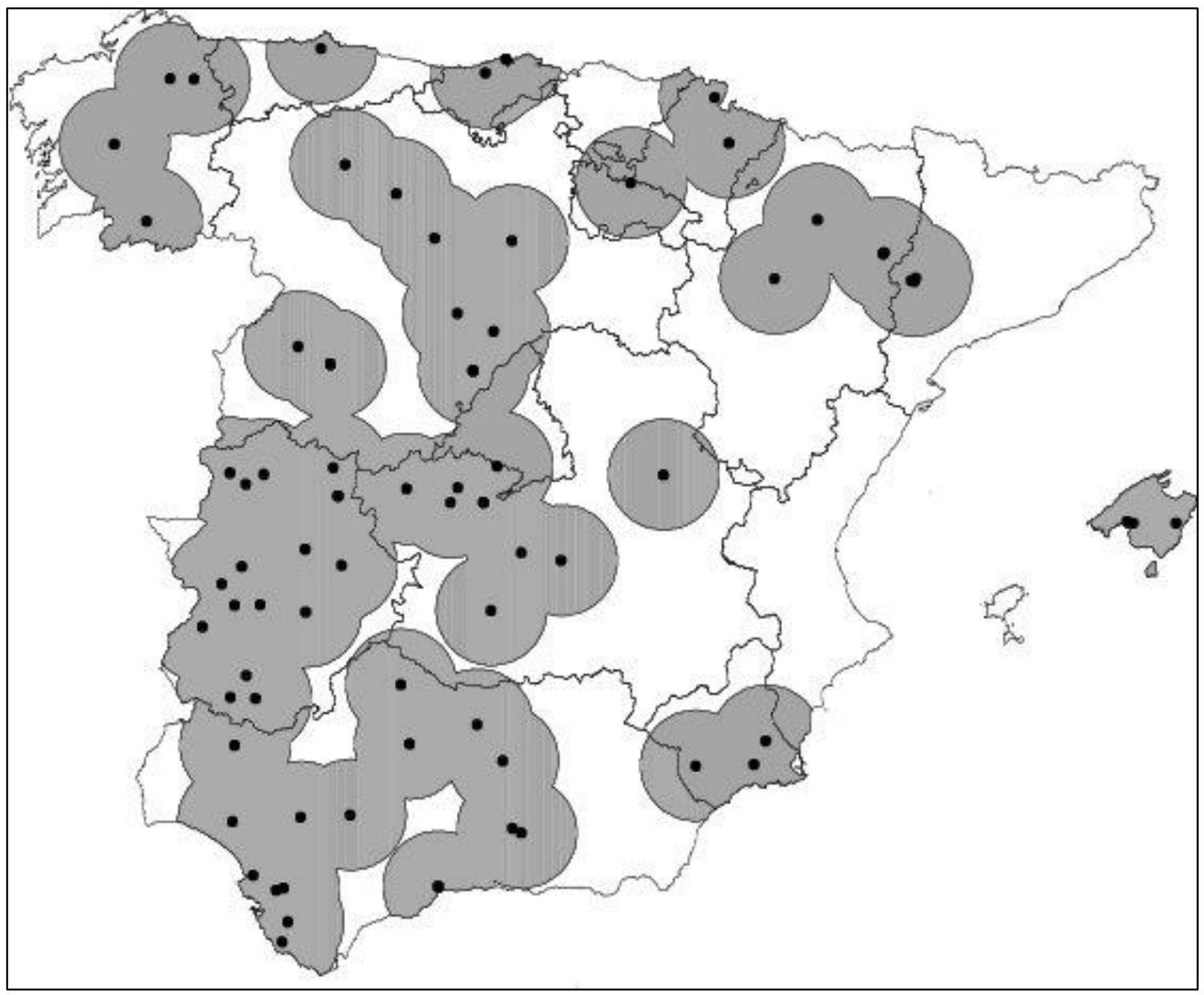

Figure 2: Map of Spain showing the points of sale POS (black dots) and their $50 \mathrm{~km}$ buffer radius. One dot may include more than a single POS.

When relating the POS abundance index with the livestock rearing practices per region, we found a strong correlation in the spatial distribution for both the extensive and intensive cattle rearing (Table 3). Despite the restricted distribution range of extensive swine, a correlation of 0.97 was highly significant. We did not find the same relationship for either intensive swine or horses, however horses were at a lower density (1:10 when compared to 
swine and cattle data combined). Our data suggest a higher exposure risk in regions with higher cattle and swine densities under extensive livestock rearing systems. Of special concern is the dehesa agro-pastoral system, which is a region that includes nearly $25,000 \mathrm{~km}^{2}$ of
Extremadura (EX), Andalusia (AN), Castilla la Mancha (CL), Castilla Leon (CM) and Madrid (MA), where livestock freely graze the whole year round because of a mild climate and food availability.

Table 3: Spearman correlation coefficients between point of sale (POS) abundance index and livestock raising types. Cattle, swine and horse individual densities were calculated as individuals $\mathrm{km}^{-1}$

\begin{tabular}{l|c|c|c} 
Livestock / raising & POS abundance /region & $\mathrm{P}$ & $\mathrm{n}$ \\
\hline Cattle & & & \\
Extensive & 0.73 & $\mathbf{< 0 . 0 5}$ & 16 \\
Intensive & 0.65 & $<\mathbf{0 . 0 5}$ & 16 \\
& & \\
Swine & 0.97 & $\mathbf{< 0 . 0 5}$ & 5 \\
Extensive & -0.05 & n.s. & 16 \\
Intensive & -0.00 & n.s. & 16
\end{tabular}

Finally, the POS overlap with the distribution of breeding vulture ranges was highest for the Cinereous Vulture (88\%), intermediate for the Egyptian and Griffon vultures (62 and 58\% respectively) and lowest for the Bearded Vulture (42\%) (Figures S4 to S7 in Supplementary Information). In terms of population size, percentages of overlap are quite similar with $73 \%$ for the Cinereous, 56-57\% for the Egyptian and Griffon and $36 \%$ for the Bearded vulture (Table S4, Supplementary Information).

\section{Discussion}

Despite the incomplete assessment for certain regions where there were no respondents, our results show how widespread diclofenac already was in Spain in 2014. After its approval in 2013, distribution and prescription to farmers was still at their early stages. Thus, the current situation must be considered as a minimum and a coarse picture. There may also be limitations to the methodology due to the difficulty of identifying those farmers using veterinary diclofenac. However, this first step is the basis on which future research and field investigations can validate and extend our results.

The relationship between the POS abundance index and livestock densities suggests the preferential use of diclofenac in both extensive swine operations and all types of cattle rearing operations. Whilst extensive cattle are spread all over the country, mainly at pastures in the mountains, extensive swine operations are concentrated in five regions in Central and south-western Spain where the dehesa spreads out (Table 2). Both in mountain ranges and the dehesa landscape, carcasses are usually located first by vultures, not by farmers or shepherds. In areas like these, it has been demonstrated that the carcass removal programs designed to control against BSE were not sufficient to 
achieve removal of all dead animals, partly because of inaccessibility due to landscape features but also because of the higher costs of carcass removal (Camiña 2012).

Disposal procedures did not change with the BSE crisis, only the amount and type of food and the number of sites where food was available. In the case of intensive swine farming, except in the northern coastal regions where animal numbers are quite small and carcasses rarely available, at regions such as Aragón (AR), Rioja (LR) and certain areas of Castilla León (CL) carcasses are disposed of in large numbers at feeding stations (Supplementary material photo S9). For example, Aragón alone provided vultures with a range of 1,360-1,460 $\mathrm{t}$ of carcasses per year at the 52 feeding sites (Table 4), all of which came from intensive swine farming activity (Gobierno de Aragón, unpub. official data). Feeding stations were once widespread and almost every village or farm had one. Dumping carcasses was a common practice based on the ecosystem services vultures provide by quickly removing carcasses from the landscape (Şekercioğlu et al. 2004). After BSE appeared, swine have been almost the only carcasses supplied at vulture feeding stations despite the EU allowances for other livestock and an expected increase in the number of feeding stations according to the latest regulation changes in carcass disposal (European Commission 2011). We do not consider the exposure of vultures to diclofenac to be affected by intensively farmed cattle, as carcasses from this livestock system are no longer available since the enactment of BSE carcass disposal regulations. The availability of horses is very low because of their respective small numbers (pers. obs., Supplementary Material photo S11).
The potential exposure to diclofenac of European vultures is quite similar for each of the four species, when considering either their distribution or population size. However, other vulture populations in Portugal (Del Moral \& Martí 2002) and French Pyrenean Griffon and Bearded vulture populations may also be exposed to diclofenac, especially when considering the large proportion of immature Griffon Vultures visiting southern Spain during their first years of dispersal and migration. Information about wintering vultures in the Iberian Peninsula is only available for the Griffon Vulture in Andalusia with 14,00015,000 birds recorded there in 2007-2009 (Junta de Andalucía 2010). This vulture wintering area also extends to Extremadura and Castilla La Mancha, where many marked juvenile or immature Griffons and Cinereous are re-sighted.

The exposure of carrion-eating birds to diclofenac depends on four factors. First, farmer access to diclofenac by veterinary prescription in their respective areas. Second, the use of diclofenac according to the livestock farming practices "extensive" versus "intensive" (see methods); it has been suggested that certain livestock rearing practices require less use of veterinary medicines. Thirdly, carcass disposal procedures determine if treated corpses are either incinerated, dropped off in the field or sent to feeding stations. Fourth, diclofenac exposure also depends on carcass availability to vultures, i.e. the access vultures have to feed on treated carcasses. Neither a direct questionnaire to shepherds, as there are 215,769 farms all over the country (INE 2014), nor public data available from the Spanish Agency for Medicines (AEMPS) about use of veterinary drugs or medicated livestock has been available prior to this study. Only rough estimates on animals requiring treatment were provided by 
the AEMPS \& MAGRAMA (2014) report, assuming that vultures only die from diclofenac poisoning if a threshold dose per unit vulture body weight was exceeded (Green et al. 2016). AEMPS \& MAGRAMA (2014) minimize the potential risk to vultures, considering it is enough to advise farmers on the drug prospectus to not use diclofenac for treatment of extensive livestock. Green et al. (2016) concluded that the most influential variable to estimate the potential threat to vultures is the time elapsed between administration of diclofenac and the death of the treated ungulate. Thus, they suggest to measure for diclofenac residues in tissues collected from feeding stations. Already in 2002-2005, prior to the massive carcass removal following BSE prevention, we collected vials of up to 100 different veterinary drugs used for livestock treatments uncontrolled and abandoned at vulture restaurants (pers. Obs. ESM photo S12). However, sampling from feeding stations could not be enough as this study shows. Carcasses from treated livestock in the "extensive" grazing areas also pose a risk, possibly even more when compared with feeding stations. After changes in carcass disposal regulations for necrophagous birds, farmers are allowed to leave the carcasses where the animal dies without the need to be moved to a feeding station (Official Journal of the European Union 2011). Vultures usually feed on carcasses shortly after animal's death, with the farmer locating the carcass thanks to them. Keeping treated carcasses out of the vulture food chain it is not a solution for farmers due to current management practices, and it is even more difficult for them to separate treated and non-treated carcasses and cover the removal costs for such cases.

There is a need for Local Governments to test for NSAIDs in vultures at wildlife rehabilitation centres because cases could easily go undetected or be confused with other poisoning incidents (Richards et al. 2014). In fact, Zorrilla et al. (2014) have described for the first time flunixin residues and traces of ketoprofen in a dead Griffon vulture from 2012, prior to the diclofenac authorisation, in one of the risky regions we have suggested here. Ketoprofen was found to be toxic for Gyps vultures already (Naidoo et al 2009), and both flunixin and ketoprofen are in use in Spain since 1994 and 1997 respectively. Thus, the lack of vulture NSAID-caused deaths does not relate to no use of these drugs, but probably a lack of specific analysis. Finally, in relation to the diclofenac prescription, a dose $(0.5-1 \mathrm{ml} / 20 \mathrm{~kg}$ for $1-3$ days) has a withdrawal period of 12-15 days for swine or cattle meat respectively if intended for human consumption. However, there is no withdrawal period for provisioning vultures and these carcasses are normally dropped off at the same time or 1-2 days after last death. Dolofenac vials contain $100 \mathrm{ml}$ - an amount that enables more than a single treatment dose - and unless strict veterinarian practice is applied, a single prescription can be used to treat several individual animals, increasing the risk of diclofenac residues in more carcasses than would be expected.

The cornerstone regulation for nature conservation in the European Union is the Birds Directive. This directive ensures that the $28 \mathrm{EU}$ Member States will guarantee the protection of necrophagous birds. It is time to find compatible solutions for livestock care and vulture conservation, learning from the massive decline of Asian populations due to the use of diclofenac. Safe alternative veterinary NSAIDs exist, such as has been demonstrated with Meloxicam, which has a lower toxicity for Cape 
vultures (Gyps coprotheres) (Naidoo et al. 2008, 2009).

\section{Acknowledgements}

We thank the Andalusia Government (R. Arenas) and J.R. Garrido for the wintering data of vultures in Andalusia. Maggie Hirschauer reviewed and greatly improved the English.

Keywords: Carcass, Europe, NSAID, threat, veterinary drug, vultures

\section{References}

AEMPS \& MAGRAMA. 2014. Análisis del riesgo de uso de medicamentos veterinarios con Diclofenaco sobre las poblaciones de buitres en España: Recomendaciones de actuación y escenarios. D. Generales de Calidad y Evaluación Ambiental y Medio Natural, D. Sanidad de la Producción Agraria del Ministerio de Agricultura, Alimentación y Medio Ambiente, Agencia Española de Medicamentos y Productos Sanitarios del Ministerio de Sanidad, Servicios Sociales e Igualdad. Unpublished report. $30 \mathrm{pp}$.

Camiña, A. 2004. Consequences of Bovine Spongiform Encephalopathy (BSE) on breeding success and food availability in Spanish vulture populations. Pp: 27-44. In Chancellor, R.D. \& B. U. Meyburg (Eds.). Raptors Worldwide. World Working Group on Birds of Prey WWGBP/MME.

Camiña, A. 2012. Sanidad ganadera y alimentación suplementaria: necesidades de investigación. In Dobado, P.M., Arenas R., Coords. 2012.The Black Vulture: Status, Conservation and Studies. Córdoba: Consejería de Medio Ambiente de la Junta de Andalucía; 2012: 194-210.

Camiña, A. \& Montelío, E. 2006. Griffon vulture Gyps fulvus food shortages in the Ebro Valley (NE Spain) caused by regulations against Bovine Spongiform Encephalopathy (BSE). Acta Ornithologica 41: 1-8.

Camiña, A., Garrido, J.R., Martin, J., Lopez-Hernandez, C.H. \& Alfaro, R. 2014. A new threat for European vultures. Science 344 (6180): 150.

Costillo, E., Corbacho, C., Sánchez, J.M. \& Villegas, A. 2007. Áreas de campeo. In, R.MorenoOpo and F. Guil (Coords.) Manual de gestión del hábitat y de las poblaciones de buitre negro en España. Ministerio de Medio Ambiente. Madrid.

Cuthbert, R., Green, R.E., Ranade, S., Saravanan, S., Pain, D.J., Prakash, V. \& Cunningham, A.A. 2006. Rapid population declines of Egyptian vulture (Neophron percnopterus) and red-headed vulture (Sarcogyps calvus) in India. Animal Conservation 9: 349-354. 
Cuthbert, R., Taggart, M.A., Prakash, V., Saini, M., Swarup, D., Upreti, S., Mateo, R., Chakraborty, S.S., Deori, P. \& Green, R.E. 2011. Effectiveness of action in India to reduce exposure of Gyps vultures to the toxic veterinary drug Diclofenac. PloS One 6(5): e19069.

De la Puente, J., Moreno-Opo, R. \& Del Moral, J.C. 2007. El buitre negro en España. Censo Nacional (2006). SEO/BirdLife. Madrid.

Del Moral, J.C. Editor. 2009. El buitre leonado en España. Población reproductora en 2008 y método de censo. SEO/BirdLife. Madrid.

Del Moral, J.C. \& Martí, R. Editors. 2002. El Alimoche Común en España y Portugal (I Censo Coordinado). Año 2000. Monografía no 8. SEO/BirdLife. Madrid.

Donázar, J.A., Naveso, M.A., Tella, J.L. \& Campión, D. 1997. Extensive grazing and raptors in Spain. In: Farming and birds in Europe: The Common Agricultural Policy and its implications for bird conservation. D. Pain \& M. Pienkowski (Eds.), pp. 117-149. Academic Press, London.

European Commission 2011. Regulation (EU) No 142/2011 of 25 February 2011 implementing Regulation (EC) No 1069/2009 of the European Parliament and of the Council laying down health rules as regards animal by-products and derived products not intended for human consumption and implementing Council Directive 97/78/EC as regards certain samples and items exempt from veterinary checks at the border under that Directive.

European Medicines Agency EMA 2009. Committee for medicinal products for Veterinary use. European Public maximum residual limits assessment report. Diclofenac (2) Bovine Milk. EMEA/CVMP/67421/2009. London 16th July 2009. 6 pp.

Green, R.E., Newton, I., Shultz, S., Cunningham, A.A., Gilbert, M., Pain, D.J. \& Prakash, V. 2004. Diclofenac poisoning as a cause of vulture population declines across the Indian subcontinent. Journal of Applied Ecology 41: 793-800.

Green, R.E., Donázar, J.A., Sánchez-Zapata, J.A. \& Margalida, A. 2016. Potential threat to Eurasian griffon vultures in Spain from veterinary use of the drug diclofenac. Journal of Applied Ecology 53: 993-1003.

INE 2014. Instituto Nacional de Estadística. Censo Agrario Nacional .2009. Available at www.ine.es [Accessed on 5th May 2014].

Junta de Andalucía 2010. Programa de emergencias, control epidemiológico y seguimiento de fauna silvestre en Andalucía. Consejería de Medio Ambiente, Junta de Andalucía, 46 pp.

López-López, P., García-Ripollés, C. \& Uríos, V. 2014. Food predictability determines space use of endangered vultures: implications for management of supplementary feeding. Ecological Applications 24: 938-949.

Margalida, A., Sanchez-Zapata, J.A., Blanco, G., Hiraldo, F. \& Donázar, J.A. 2014. Diclofenac approval as a threat to Spanish vultures. Conservation Biology 28: 631-632. 
Markandya, A., Taylor, T., Longo, A., Murty, M., Murty, S. \& Dhavala, K. 2008. Counting the cost of vulture decline-An appraisal of the human health and other benefits of vultures in India. Ecological Economics 67: 194-204.

Monsarrat, S., Benhamou, S., Sarrazin, F., Bessa-Gomes, C., Bouten, W. \& Duriez, O. 2013. How does predictability of feeding patches affect home range and foraging habitat selection in avian social scavengers? PloS One 8(1): e53077.

Naidoo, V., Wolter, K., Cromarty, A.D., Bartels, P., Bekker, L., McGaw, L., Taggart, M.A., Cuthbert, R. \& Swan, G.E. 2008. The pharmacokinetics of meloxicam in vultures. Journal of Veterinary Pharmacology and Therapeutics 31: 128-134.

Naidoo, V., Wolter, K., Cromarty, A.D., Diekmann, M., Duncan, N., Meharg, A.A., Taggart, M.A., Venter, L. \& Cuthbert, R. 2009. Toxicity of non-steroidal anti-inflammatory drugs to Gyps vultures: a new threat from ketoprofen. Biology Letters 6: 339-341.

Official Journal of the European Union. 2011. COMMISSION REGULATION (EU) No 142/2011 of 25 February 2011implementing Regulation (EC) No 1069/2009 of the European Parliament and of the Council laying down health rules as regards animal by-products and derived products not intended for human consumption and implementing Council Directive 97/78/EC as regards certain samples and items exempt from veterinary checks at the border under that Directive. $\mathrm{L}$ 54/1 26.02.2011

Oaks, J.L., Gilbert, M., Virani, M.Z., Watson, R.T., Meteyer, C.U., Rideout, B.A., Shivaprasad, H.L., Ahmed, S., Chaudhry, M.J.I., Arshad, M., Mahmood, S., Ali, A. \& Khan, A.A. 2004. Diclofenac residues as the cause of vulture population decline in Pakistan. Nature 427(6975), 630-633.

Prakash, V., Pain, D.J., Cunningham, A.A., Donald, P.F., Prakash, N., Verma, A., Gargi, R., Sivakumar, S., Rahmani, A.R. 2003. Catastrophic collapse of Indian white-backed Gyps bengalensis and longbilled Gyps indicus vulture populations. Biological Conservation 109: 381390.

Razin, M. 2014. Gypaete Barbu. Pyrenees Versant Nord. Circulaire nº 67.10 pp.

Richards, N., Hall, S.H., Harrison, N.M., Gautam, L., Scott, K.S., Dowling, G., Zorrilla, I., Fajardo, I. 2014. Merging Wildlife and Environmental Monitoring Approaches with Forensic Principles: Application of Unconventional and Non-Invasive Sampling in Eco-Pharmacovigilance. Journal of Forensic Research 5(3): 228

Şekercioğlu, C.H., Daly, G.C., Ehrlich, P.E. 2004. Ecosystem consequences of bird declines. PNAS 101(52):18042-18047.

Swan, G.E., Cuthbert, R., Quevedo, M., Green, R.E., Pain, D.J., Bartels, P., Cunningham, A.A., Duncan, N., Meharg, A.A., Oaks, J.L., Parry-Jones, J., Shultz, S., Taggart, M.A., Verdoorn, G., Wolter, K. 2006a. Toxicity of diclofenac to Gyps vultures. Biology Letters 2(2): 279-282. 
Swan, G., Naidoo, V., Cuthbert, R., Green, R.E., Pain D.J., Swarup, D., Prakash V., Taggart M., Bekker, L., Das, D., Diekmann, J., Diekmann, M., Killian, E., Meharg, A., Chandra Patra, R., Saini, M, \& Wolter, K. 2006b. Removing the threat of Diclofenac to Critically Endangered Asian Vultures. PloS Biology 4(3): e66.

Zorrilla, I., Martinez, R., Taggart, M. \& Richards, N. 2014. Suspected Flunixin Mortality in a Wild Eurasian Griffon Vulture from Spain. Conservation Biology. DOI: 10.1111/cobi.12417

\section{Supplementary Material}

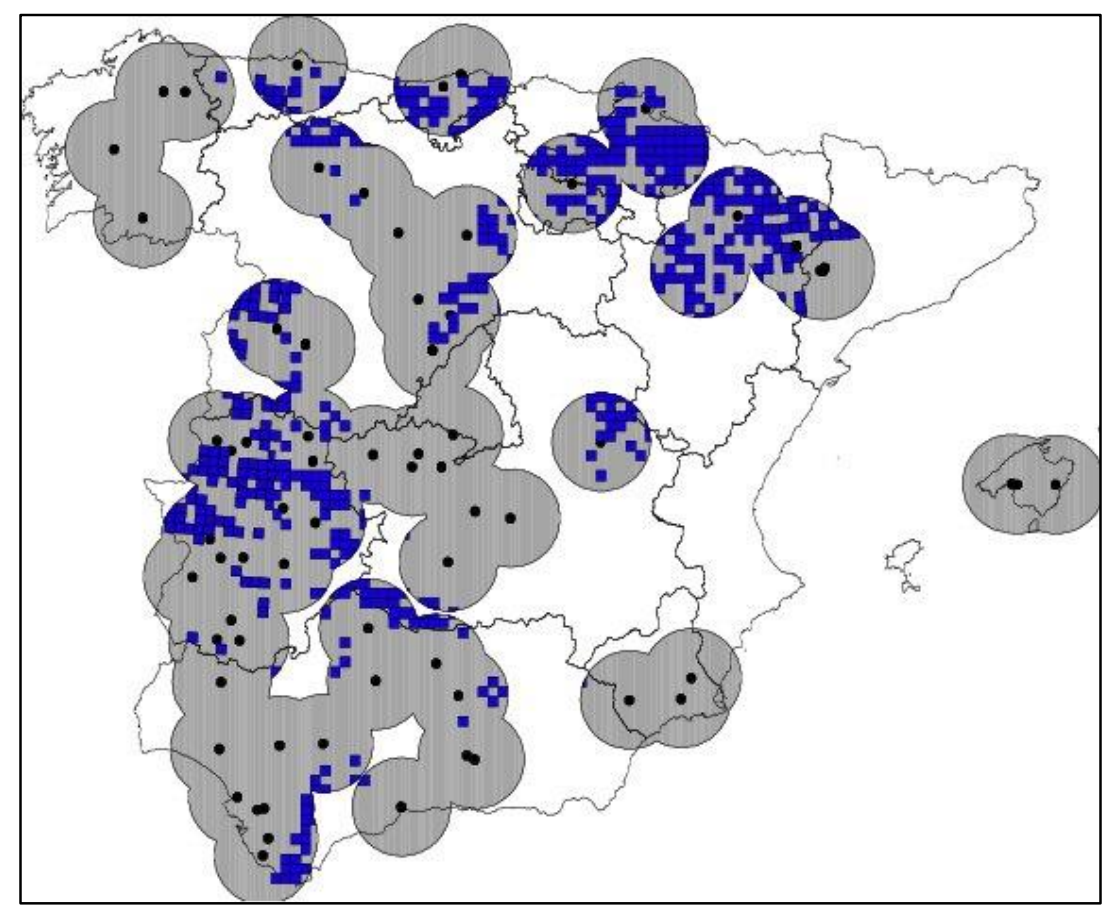

Figure S4: Overlap between the POS buffer radius and the distribution of the Egyptian Vulture in Spain (map for the Canary Islands has been omitted because no POS have been registered there). 


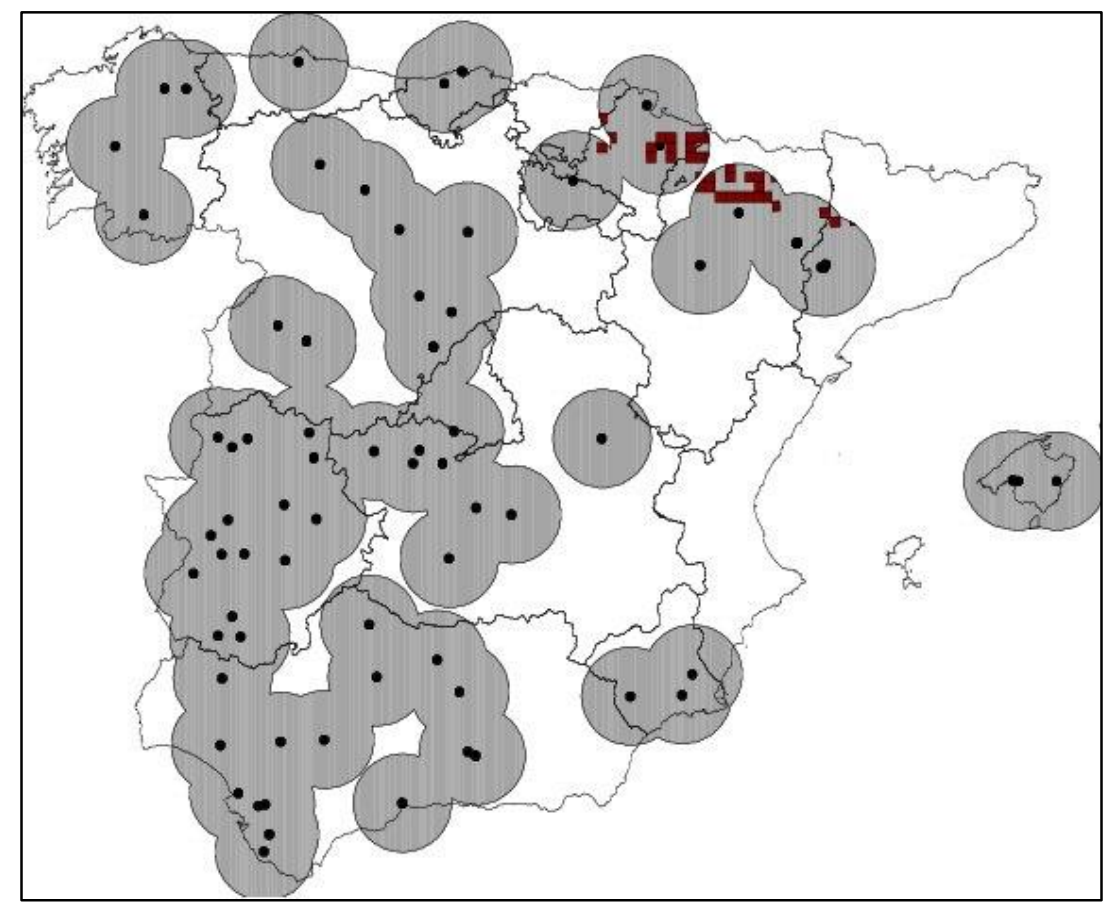

Figure S5: Overlap between the POS buffer radius and the distribution of the Bearded Vulture in Spain.

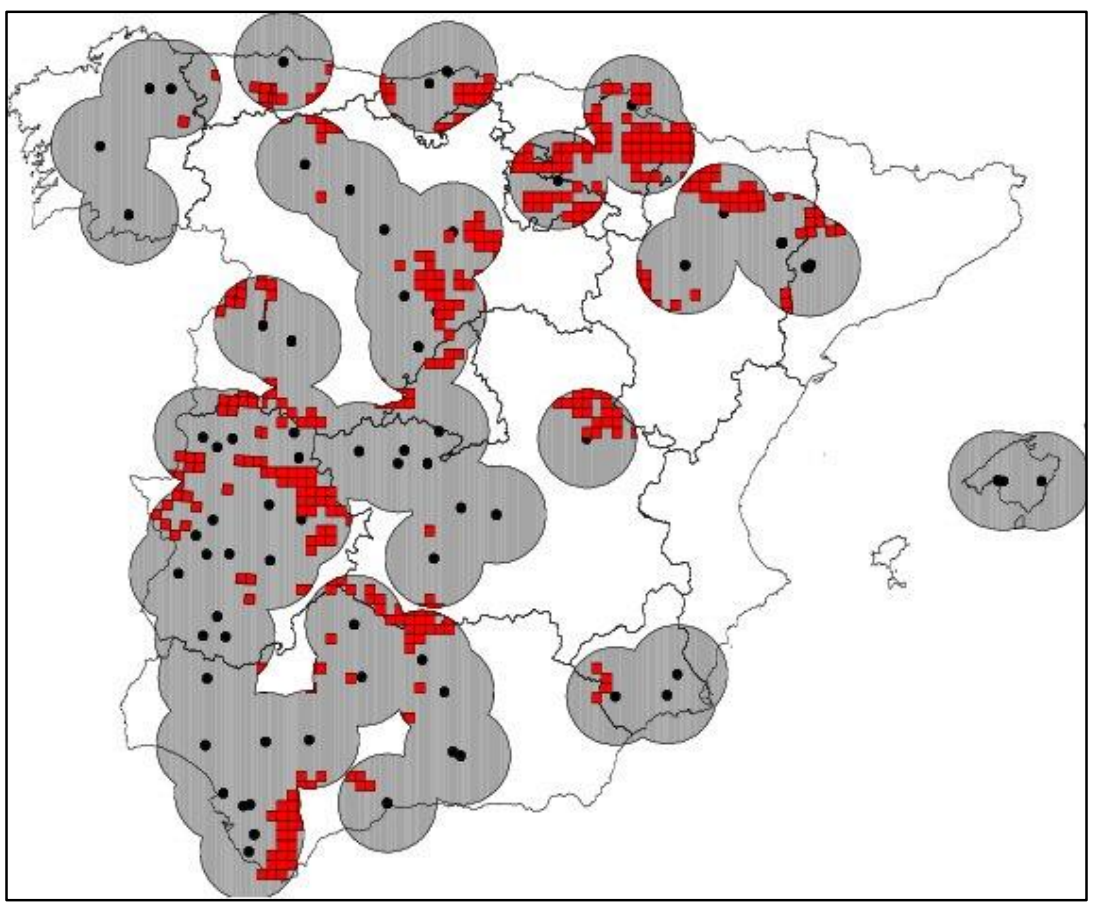

Figure S6: Overlap between the POS buffer radius and the distribution of the Griffon Vulture in Spain. 


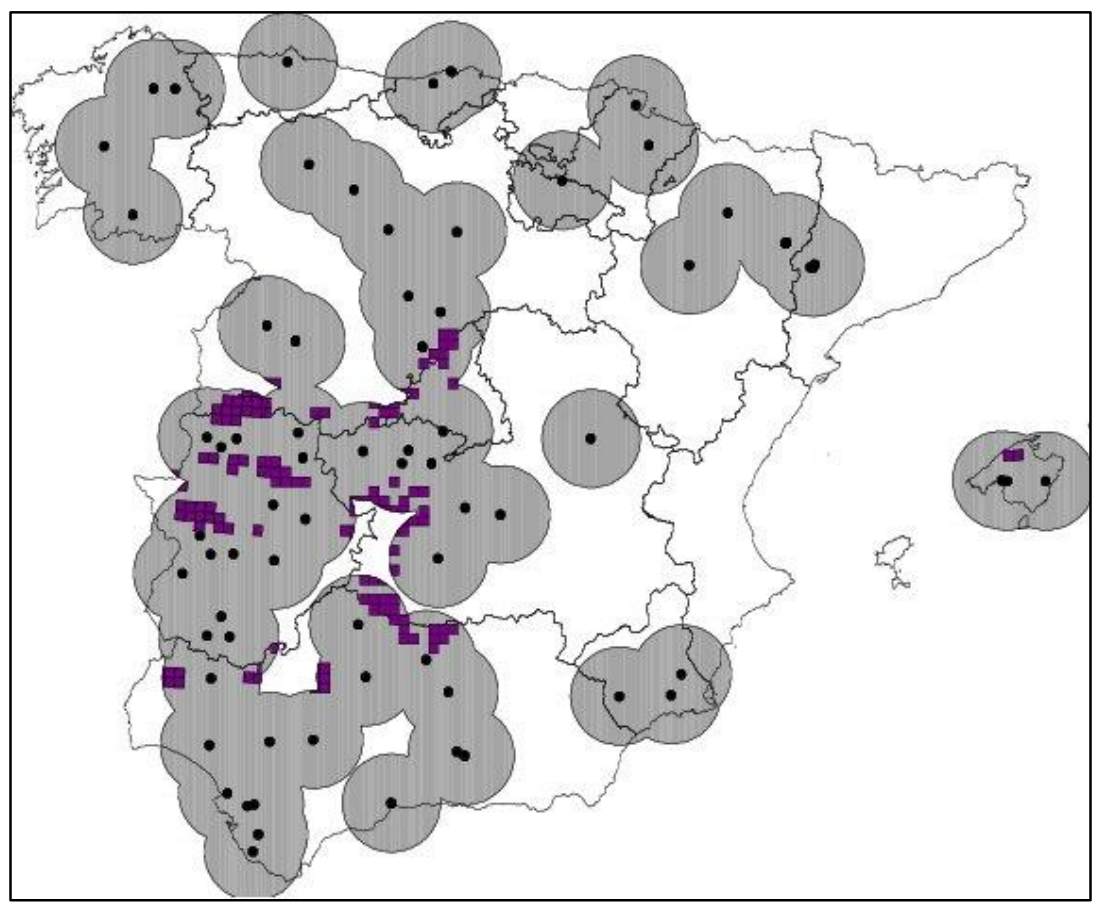

Figure S7: Overlap between the POS buffer radius and the distribution of the Cinereous Vulture in Spain.

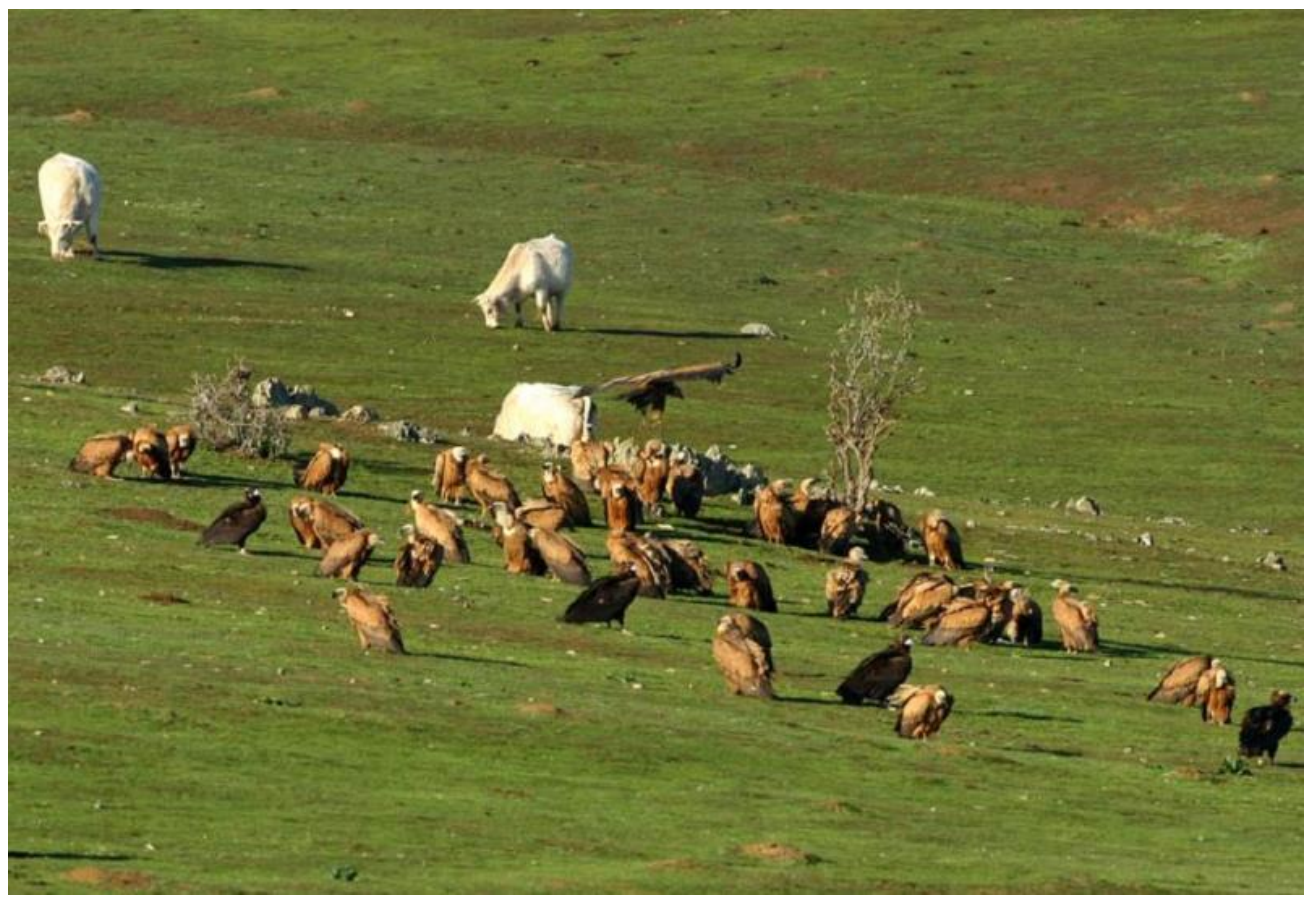

Figure S8: A group of Griffon and Cinereous vultures feeding at extensive grazing areas among cattle (R. Palomo). 


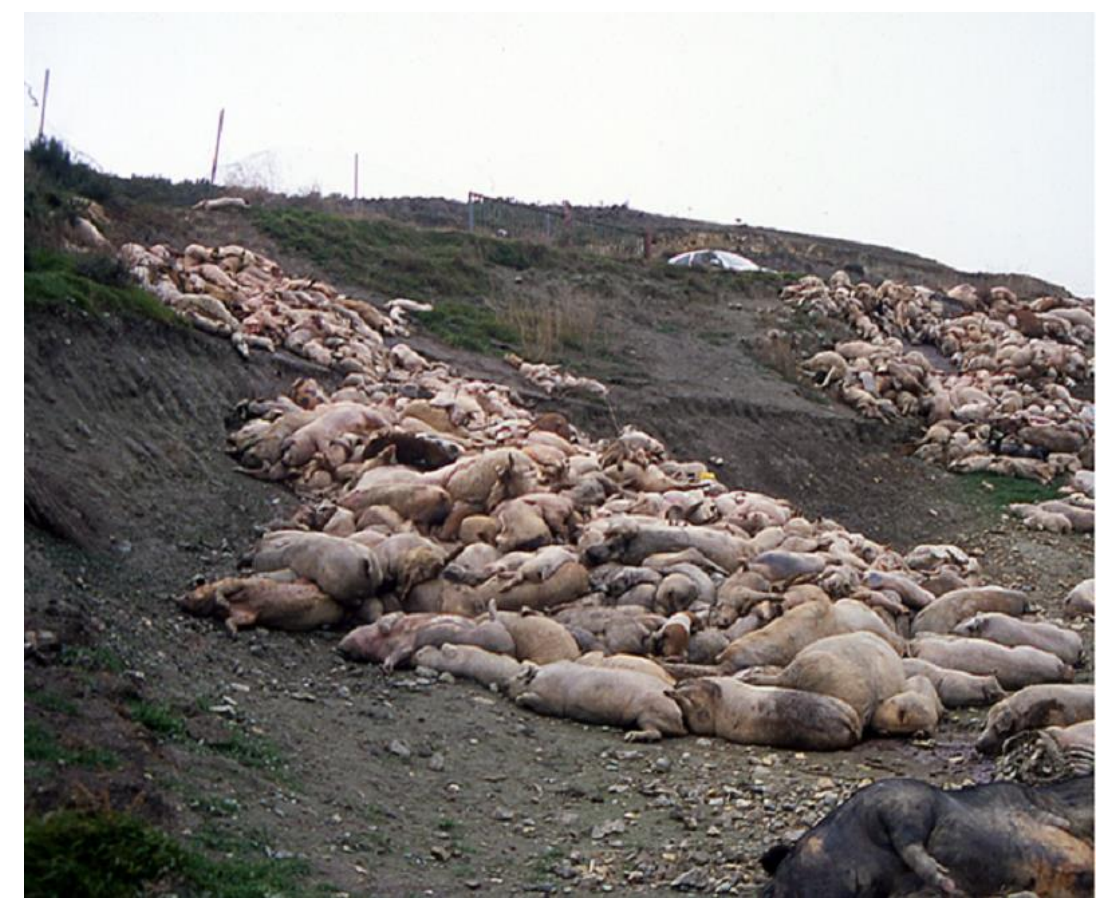

Photo S9: Swine carcasses from intensive farming at a feeding station before vultures could feed (A. Camiña).

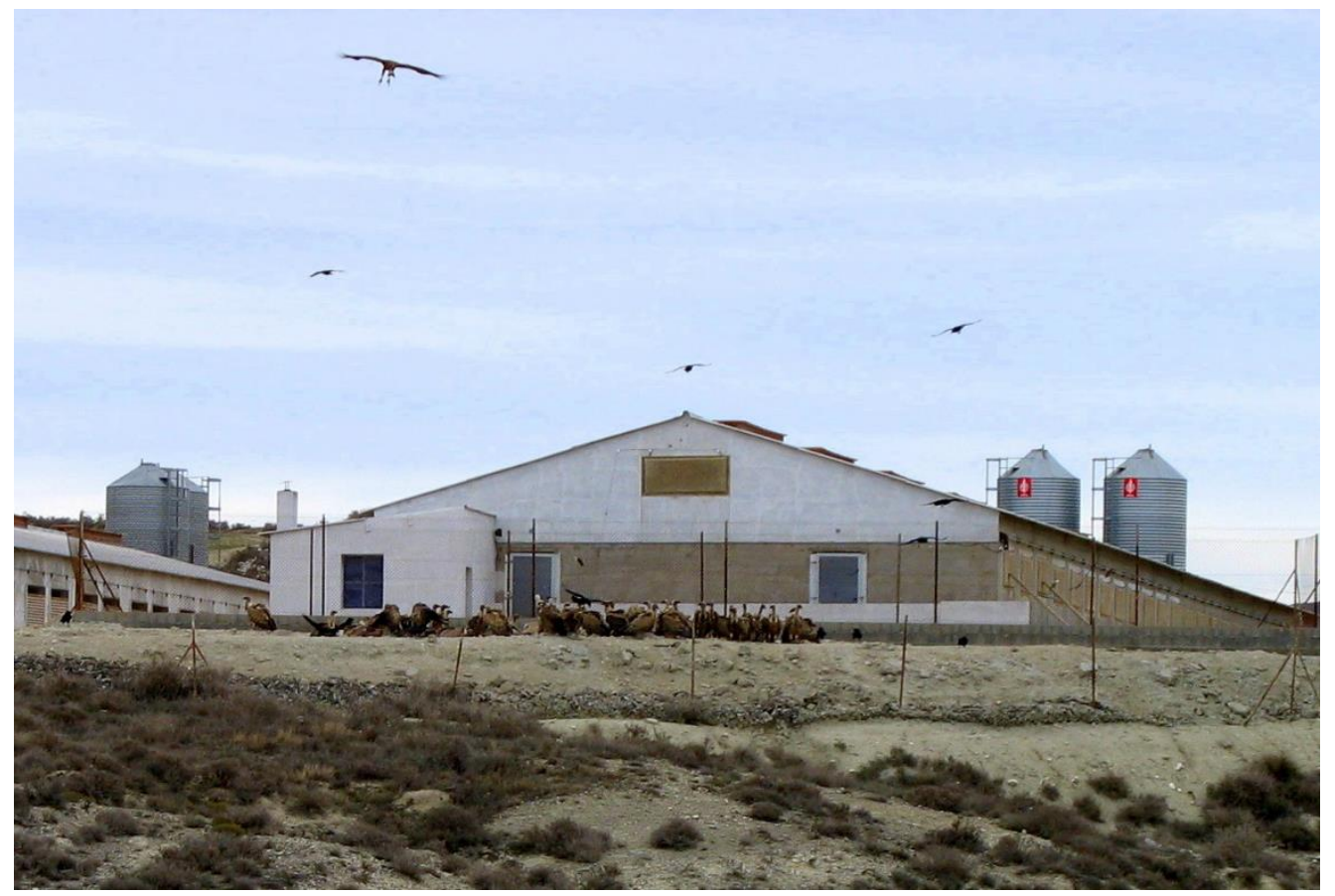

Photo S10: Griffon vultures landing and feeding from carcasses produced and disposed at an intensive swine farm, not a feeding site (A. Camiña). 


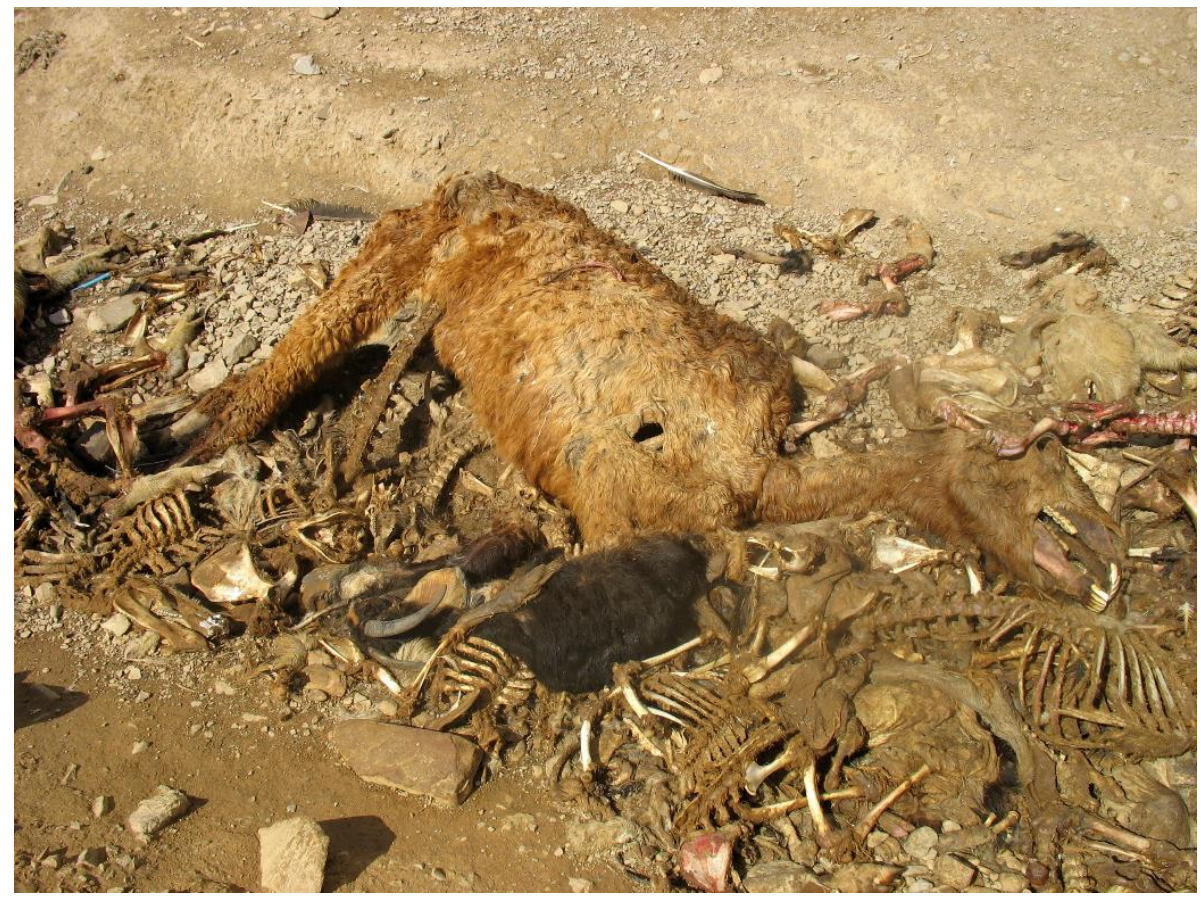

Photo S11: Horse carcass available at a vulture restaurant or muladar (A. Camiña).

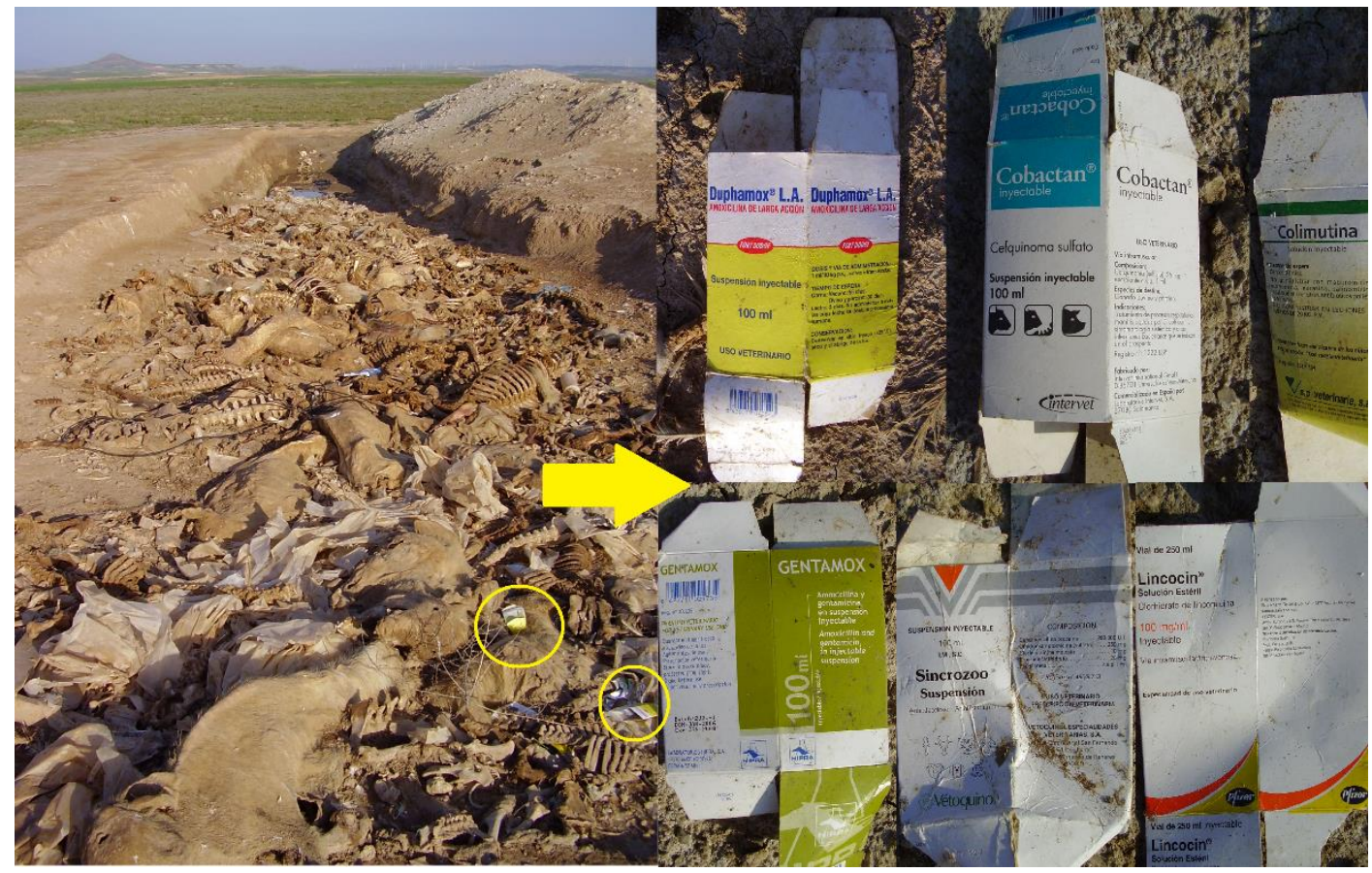

Photo S12: Veterinary drugs remains mixed with disposed carcasses at a feeding site (A. Camiña). 
Table S4: Vulture populations (breeding pairs) sorted by region: when not stated after De la Puente (2007), Del Moral \& Martí (2002) and Del Moral (2009) and number of existing feeding stations by June 2014. Total number of 10 X $10 \mathrm{~km}$ squares the species occupy in Spain and those (percentage) within the $50 \mathrm{~km}$ buffer radius around POS.

\begin{tabular}{lccccc}
\hline Region (code) & $\begin{array}{c}\text { Feeding } \\
\text { stations }\end{array}$ & G. fulvus & N. percnopterus & A. monachus & G. barbatus \\
\hline Andalusia (AN) & 38 & 2978 & 34 & $330^{(4)}$ & - \\
Aragon (AR) & 52 & $5174^{*}$ & 267 & - & $83^{(6)}$ \\
Asturias (AS) & 1 & 151 & 66 & - & - \\
Basque Country (BC) & 2 & 805 & 48 & - & - \\
Canary islands (CI) & 1 & - & 42 & - & - \\
Cantabria (CAN) & 0 & 467 & 51 & - & - \\
Castilla La Mancha (CM) & 22 & 2410 & 163 & 367 & - \\
Castilla Leon (CL) & 49 & 5965 & 422 & 287 & - \\
Catalonia (CAT) & 19 & $939^{*}$ & 70 & $68^{(2)}$ & - \\
Extremadura (EX) & 15 & 1560 & 179 & $897^{(3)}$ & - \\
Galicia (GA) & 0 & - & - & - & - \\
Balearic Islands (BI) & 3 & $10^{(1)}$ & 51 & $18^{(5)}$ & - \\
La Rioja (LR) & 5 & 639 & 20 & - & - \\
Madrid (MA) & 1 & 461 & - & 89 & - \\
Murcia (MU) & 1 & 55 & - & - & - \\
Navarre (NA) & 15 & $2783^{(6)}$ & 127 & - & - \\
Valencia (VA) & 4 & 253 & 14 & - & 129 \\
\hline TOTAL & 228 & 24650 & 1554 & 1994 & 90 \\
\hline Total \# 10x10 UTM & & 752 & 947 & 158 & $38(42 \%)$ \\
\# squares within 50 km & & $434(58 \%)$ & $582(62 \%)$ & $139(88 \%)$ & \\
(\% overlap) & & & & & \\
\hline
\end{tabular}

Notes: (1) Data updated for 2013-2014 (J. Majol and J. Muntaner pers. com.), Official data from the Government of the Balearic Islands. (2) Annual monitoring data 2013 Catalonian Government. (3) Annual Official census data from the Junta de Extremadura Government 2013. (4) R. Arenas (2013) Annual surveillance programme for the Cinereous Vulture in Andalusia. (5) Data updated for 2013-2014 (J. Majol and J. Muntaner pers. com.), Official data from the Government of the Balearic Islands. (6) Martine Razin (pers. comm.) Gypaete Barbu. Pyrenees Versant nord. Circulaire $n^{\circ}$ 64. October 2013. 3 pp. There are another 36 territories in the French Pyrenees plus 1 in Andorra. (7) Data increase with the nearly 900 Griffon Vulture breeding pairs on the Northern side of the Pyrenees. 